\title{
Yolk Color and Lipid Oxidation of the Eggs of Commercial White Layers Fed Diets Supplemented with Vegetable Oils
}

\section{-Author(s)}

\author{
Faitarone ABG \\ Garcia EA" \\ Roça RO"I \\ Andrade EN ${ }^{I V}$ \\ Vercese $\mathrm{F}^{\mathrm{V}}$ \\ Pelícia $\mathrm{K}^{\mathrm{VI}}$
}

Post-doctoral, Department of Agribusiness Management and Technology, FCA, Unesp Botucatu, SP, Brazil.

" Prof. Head Professor, Department of Animal Production, FMVZ, Unesp, Botucatu, SP, Brazil.

III Prof. Associate Professor, Department of Agribusiness Management and Technology, FCA, Unesp, Botucatu, SP, Brazil.

iv Ph.D. in Animal Science, FMVZ, Unesp, Botucatu, SP, Brazil.

$\checkmark$ Ph.D. in Animal Science, FMVZ, Unesp, Botucatu, SP, Brazil.

v1 Professor, Department of Animal Science, UNIFENAS, Alfenas, MG, Brazil.

\section{Mail Address}

Corresponding author e-mail address Ana Beatriz Garcia Faitarone

Rua Professor Antônio Ruete, 81 - Nova Jaboticabal - Jaboticabal - SP - Brasil CEP 14887-032

E-mail: abiazinha2003@yahoo.com.br

\section{- Keywords}

Polyunsaturated fatty acids, yolk color canola oil, linseed oil, soybean oil, TBÁRs.

\section{ABSTRACT}

The objective of this study was to evaluate the influence of the supplementation of vegetable oils rich in polyunsaturated fatty acids to the diet of Leghorn layers on yolk color and on yolk lipid oxidation of eggs stored at room temperature for 10 days. Sixty eggs laid by commercial white layers (Lohmann LSL) fed diets supplemented with different vegetable oils were used. Hens were fed one of the following treatment diets: conventional diet with no oil inclusion (T1); T1 diet with $2.5 \%$ linseed oil inclusion (T2); T1 diet with 2.5\% canola oil (T3); T1 diet with $2.5 \%$ soybean oil (T4); T1 with $5.0 \%$ linseed oil (T5); T1 diet with $5.0 \%$ canola oil (T6); T1 diet with $5.0 \%$ soybean oil (T7); T1 diet with $2.5 \%$ linseed oil $+2.5 \%$ soybean oil (T8); T1 diet with $2.5 \%$ canola oil $+2.5 \%$ soybean oil (T9); and T1 diet with $2.5 \%$ linseed oil + $2.5 \%$ canola oil (T10). Eggs were evaluated as to yolk lipid peroxidation (TBARS values) and yolk color, as determined by colorimetry and subjective sensorial analysis. Data were submitted to analysis of variance and means were compared by the test of Tukey at $5 \%$ significance level. It was concluded that the inclusion of vegetable oils in commercial white layer diets does not significantly change egg yolk pigmentation, as colorimetrically evaluated. However, when subjectively assessed, the yolks of the eggs laid by hens fed diets supplemented with vegetable oils tend to be paler. The yolks of the eggs laid by layers fed diets containing sources of polyunsaturated fatty acids presented high lipid oxidation, particularly when compared with those derived from layers fed the diet with no oil supplementation.

\section{INTRODUCTION}

Egg quality have different meanings, according to egg producers', consumers', and processors' perspectives. The main egg quality aspects considered by egg producers are egg weight and eggshell quality, whereas consumers are interested in shelf life, external appearance, and sensorial qualities, such as eggshell and yolk color. On the other hand, processors take into account easy eggshell removal and separation of the yolk from the albumen, as well as egg functional properties (Alleoni \& Antunes, 2001).

The contents of egg components maybe changed by the diet, and the inclusion of specific ingredients in layer feeds have been used to change the yolk lipid profile and to improve yolk quality. The use of nutritional strategies to improve the quality and change the composition of animal products used for human consumption links animal production with food technology and nutrition (Szymozyk \& Pisulewiski, 2003).

When added to layer diets, lipids increase dietary energy density; improve diet palatability; reduce heat increment, increasing energy metabolism efficiency; and change egg yolk composition (Braga \& Baião, 2001).
Submitted: June/2015 Approved: February/2016 
Some of the fatty-acid sources added to layer diets are linseed oil (used for the production of $\omega-3$ enriched oil), soybean oil and sunflower, which are used as sources of mono- and polyunsaturated fatty acids (Baucells et al., 2000; Schreiner et al., 2004).

The use of linseed oil in layer diets enriches the egg as it increases the egg content of unsaturated fatty acids, particularly of linolenic acid, as well as by the incorporation of small amounts of eicosapentaenoic acid (EPA) and doxosahexaenoic acid (DHA) in the yolk.

Most of egg lipids are in the form of yolk lipoproteins ( $4 \mathrm{~g}$ of its average weight), with the lipids associated with the proteins vitelline and vitellinin. The lipid profile of the egg yolk is influenced by genetics, egg size, feed composition, and type of fat added to feed (Barreto et al., 2006; Cherian, 2008).

The main yolk fatty acids are oleic acid (38\%), palmitic acid (23\%), and linoleic acid (16\%), according to Grosch (1997). Botsoglou et al.(1998) reported that chicken eggs contain $33.84 \%$ saturated fatty acids and $45.26 \%$ monounsaturated fatty acids, and $17.63 \%$ and $2.34 \%$ polyunsaturated fatty acids of the series $\omega-6$ and $\omega-3$, respectively.

Among yolk sensorial attributes, its color is considered as a quality indicator, and plays an important role of egg acceptance by the consumers. Higher yolk color intensity increases the egg acceptance by the consumers, who associated more intense yolk pigmentation with higher egg nutritional value (Silva et al., Albino \& Godói, 2000; Tocchini \& Mercadante, 2001).

Yolk color intensity is determined by the incorporation of xanthophylls present in corn, particularly of lutein and zeaxanthin, and depends on the inclusion levels of yellow corn in layer diets. However, other feedstuffs may change yolk color, depending on their inclusion level (Silva et al., Albino \& Godói, 2000).

Oliveira (2008) studied the influence of dietary lipid sources on yolk color in layers, and reported more intense color when hens were fed diets with sunflower oil compared with those fed a diet that did not contain vegetable oil.

Lee et al. (2001) did not find any effect of corn oil addition to layer diets on yolk color, and concluded that changes in yolk color may be observed when supplemental carotenoid sources are added to the diet, as carotenoid pigments are fat soluble and therefore, absorbed in the intestine together with lipids.
Another important egg quality item is lipid stability, as the yolk fatty acids may suffer lipid oxidation during storage. Lipid oxidation affects food quality, particularly its aroma, taste, and nutritional value, in addition of producing toxic compounds. Fatty acids, particularly unsaturated fatty acids, are the compounds most susceptible to oxidation (Fennema, 2000). Consequently, the inclusion of polyunsaturated fatty acids in layer diets may increase the susceptibility of eggs to lipid oxidation (Cherian et al., 2007). Antioxidants, such as tocopherol, may be added to layer diets to protect fatty acids from oxidation and to enrich eggs with vitamin E (Pita et al., 2006).

Xavier et al. (2008) reported that, when stored at room temperature, the shelf life of chicken eggs ranges between four to 15 days after lay, with no impairment of their internal quality.

Despite its limitations, the typical method used to assess lipid oxidation in fatty acid-rich foods is the thiobarbituric acid (TBA) test because it is simple and fast. This test quantifies the level of malonaldehyde (MDA), which is one of the main products of the breakdown of hydroperoxides produced during the oxidation of polyunsaturated fatty acids (Osawa et al., 2005).

Foods appropriate for consumption should present lipid oxidation values below $3 \mathrm{mg}$ MDA/kg of sample, with an upper limit of 7-8 mg MDA/kg (Cadun et al., Cakli \& Kisla, 2005).

Giampietro et al. (2008) evaluated the degree of lipid oxidation using TBARS in the yolks of eggs laid by brown layers and stored for $0,7,14$, and 21 days at room temperature $\left(25^{\circ} \mathrm{C}\right)$. The authors detected yolk loss quality, as determined by progressive lipid oxidation up to 14 days of storage, and concluded that storing eggs at room temperature does not preserve egg internal quality.

Therefore, this study aimed at evaluating the influence of the supplementation of white layer diets with vegetable oils rich in polyunsaturated fatty acids on the sensorial egg characteristics and on yolk lipid oxidation of eggs stored at room temperature for 10 days.

\section{MATERIAL AND METHODS}

A total of 480 Lohmann LSL layers, with 33 weeks of age at the beginning of the experiment were used. Hens were housed in 84 metal battery cages designed 
Faitarone ABG, Garcia EA, Roça RO, Andrade EN, Vercese F, Pelícia K
Yolk Color and Lipid Oxidation of the Eggs of Commercial White Layers Fed Diets Supplemented with Vegetable Oils

2.5\% soybean oil (T9); and T1 diet with $2.5 \%$ linseed oil $+2.5 \%$ canola oil (T10)

Birds were offered feed and water ad libitum during the entire experimental period. All diets were based on corn, soybean meal, and wheat middlings. The diets were formulated to contain identical energy and protein levels, and to supply the hens' nutritional requirements, according to Rostagno et al. (2005). The only difference was the oil source included. The ingredient and calculated nutritional composition of the experimental diets are shown in Table 1.

Table 1 - Ingredients and calculated nutritional composition of the experimental diets.

\begin{tabular}{|c|c|c|c|c|c|c|c|c|c|c|}
\hline \multirow[b]{2}{*}{ Ingredients } & \multicolumn{10}{|c|}{ Treatments } \\
\hline & Control & 2 & 3 & 4 & 5 & 6 & 7 & 8 & 9 & 10 \\
\hline Ground corn & 64.20 & 52.66 & 53.05 & 53.10 & 41.17 & 41.62 & 41.75 & 41.40 & 41.80 & 41.40 \\
\hline Soybean meal & 25.60 & 24.02 & 24.10 & 24.10 & 22.31 & 22.45 & 22.48 & 22.39 & 22.47 & 22.32 \\
\hline Wheat midds & - & 10.67 & 10.22 & 10.16 & 21.44 & 20.85 & 20.69 & 21.12 & 20.66 & 21.19 \\
\hline Canola oil & - & - & 2.50 & - & - & 5.00 & - & - & 2.50 & 2.50 \\
\hline Linseed oil & - & 2.5 & - & - & 5.00 & - & - & 2.50 & - & 2.50 \\
\hline Soybean oil & - & - & - & 2.5 & - & - & 5.0 & 2.5 & 2.5 & - \\
\hline Limestone & 7.98 & 8.05 & 8.03 & 8.02 & 8.08 & 8.07 & 8.07 & 8.08 & 8.07 & 8.08 \\
\hline Dicalcium phosphate & 1.36 & 1.25 & 1.25 & 1.27 & 1.14 & 1.15 & 1.15 & 1.15 & 1.15 & 1.15 \\
\hline S alt & 0.35 & 0.35 & 0.35 & 0.35 & 0.35 & 0.35 & 0.35 & 0.35 & 0.35 & 0.35 \\
\hline DL-methionine & 0.20 & 0.19 & 0.19 & 0.19 & 0.20 & 0.20 & 0.20 & 0.20 & 0.20 & 0.20 \\
\hline Mineral supplement ${ }^{(1)}$ & 0.10 & 0.10 & 0.10 & 0.10 & 0.10 & 0.10 & 0.10 & 0.10 & 0.10 & 0.10 \\
\hline Vitamin supplement(2) & 0.10 & 0.10 & 0.10 & 0.10 & 0.10 & 0.10 & 0.10 & 0.10 & 0.10 & 0.10 \\
\hline Adsorbent & 0.10 & 0.10 & 0.10 & 0.10 & 0.10 & 0.10 & 0.10 & 0.10 & 0.10 & 0.10 \\
\hline Antioxidante (BHT) & 0.01 & 0.01 & 0.01 & 0.01 & 0.01 & 0.01 & 0.01 & 0.01 & 0.01 & 0.01 \\
\hline Total & 100.00 & 100.00 & 100.00 & 100.00 & 100.00 & 100.00 & 100.00 & 100.00 & 100.00 & 100.00 \\
\hline \multicolumn{11}{|c|}{ Calculated nutritional composition } \\
\hline Crude protein (\%) & 17.50 & 17.50 & 17.50 & 17.50 & 17.50 & 17.50 & 17.50 & 17.50 & 17.50 & 17.50 \\
\hline $\begin{array}{l}\text { ME } \\
\text { (kcal/kg feed) }\end{array}$ & 2.750 & 2.750 & 2.750 & 2.750 & 2.750 & 2.750 & 2.750 & 2.750 & 2.750 & 2.750 \\
\hline Calcium (\%) & 3.50 & 3.50 & 3.50 & 3.50 & 3.50 & 3.50 & 3.50 & 3.50 & 3.50 & 3.50 \\
\hline Available phosphorus & 0.35 & 0.35 & 0.35 & 0.35 & 0.35 & 0.35 & 0.35 & 0.35 & 0.35 & 0.35 \\
\hline Avail. lysine (\%) & 0.78 & 0.77 & 0.77 & 0.77 & 0.76 & 0.76 & 0.76 & 0.76 & 0.76 & 0.76 \\
\hline $\begin{array}{l}\text { Avail. methionine (\%) } \\
(\%)\end{array}$ & 0.44 & 0.43 & 0.42 & 0.42 & 0.43 & 0.43 & 0.43 & 0.43 & 0.43 & 0.43 \\
\hline Avail. Met+Cys (\%) & 0.50 & 0.48 & 0.48 & 0.48 & 0.48 & 0.48 & 0.48 & 0.48 & 0.48 & 0.48 \\
\hline
\end{tabular}


Table 2 shows the fatty acid composition of the vegetable oils used in the experimental diets.

Table 2 - Analyzed fatty acid composition of the vegetable oils included in the experimental diets (\% of total fatty acids).

\begin{tabular}{lccc}
\hline \multirow{2}{*}{ Fatty acids } & Canola oil & Linseed oil & Soybean oil \\
\cline { 2 - 4 } & \multicolumn{3}{c}{$\%$} \\
\hline C16:0 - Palmitic acid & 12.3751 & 6.3720 & 13.0608 \\
C18:0 - Stearic acid & 2.4502 & 3.9842 & 2.2366 \\
C18:1 - Oleic acid & 45.2735 & 24.8235 & 23.0449 \\
C18:2 - Linoleic acid $(\omega 6)$ & 36.5747 & 14.6624 & 56.4484 \\
C18:3 - Linolenic acid $(\omega 3)$ & 3.3264 & 50.1580 & 5.2094 \\
\hline
\end{tabular}

On day 60 of the experimental period, egg yolks were analyzed for TBARS levels (degree of lipid oxidation). Six eggs per treatment were collected and stored in paper pulp egg trays at environmental temperature (19 $\pm 2^{\circ} \mathrm{C}$ ) for 10 days. At the end of the storage periods, eggs were broken, and their yolks were separated and frozen. When frozen, yolks were freeze-dried by removing water and other solvents by sublimations, that is, solid-state water was directly transformed into steam, and did not pass by the liquid state. Dehydrated yolks were then analyzed for lipid oxidation (TBARS), according to the methodology described by Vyncke (1970) and modified by Ramanathan \& Das (1992).

A completely randomized experimental design, with ten treatments with six replicates of one egg each was applied.

Egg yolk color sensorial assessment was performed at the end of the experimental period using the Multiple Comparison test. Yolk color was also measured using a colorimeter (Minolta CR-400), according to Honikel (1998).

The multiple comparison sensorial test for the determination of yolk color was performed according to Roça et al. (1988), with 23 trained and selected tasters (Roça \& Bonassi, 1985). A structured scale with nine scores, ranging from $1=$ extremely less intense than the standard to $9=$ extremely more intense than the standard, was used. Eggs were cooked for $10 \mathrm{~min}$ at $96^{\circ} \mathrm{C}$, and then longitudinally cut to expose the yolks for assessment. Sensorial egg yolk color assessment was analyzed according to a completely randomized experimental design with 10 treatments of 23 replicates (panelists) each.

For egg yolk color instrumental measurements, eight eggs per treatment were duly identified, cooked for 10 min at $96^{\circ} \mathrm{C}$, and longitudinally cut to expose the yolks. Yolk color was measured using a colorimeter (Minolta CR-400) according to the methodology proposed by Honikel (1998). The colorimeter was previously calibrated against a white ceramic surface according to the standards established by Bible \& Singha (1997). The CIE (Commission Internationale de l'Éclairage) color evaluation system $\left(L^{*}, a^{*}\right.$, and $\left.b^{*}\right)$ was applied. The $L^{*}$ values correspond to luminosity, with maximum value of -100 corresponding to perfect diffuse reflection and the minimum value of 0 representing black. The $a^{*}$ value corresponds to redness, and ranges from red $\left(+a^{*}\right)$ to green $\left(-a^{*}\right)$, and the $b^{*}$ value indicates yellowness, and ranges from yellow $\left(+b^{*}\right)$ to blue $\left(-b^{*}\right)$. The $a^{*}$ and $b^{*}$ values to not have specific numerical limits. Yolk color was determined as the average of five readings in the center of the yolk of each egg. Instrumental egg color results were analyzed according to a completely randomized experimental design, with ten treatments with eight replicates (eggs) each. Data were submitted to analysis of variance (ANOVA).

The GLM (General Linear Models) procedure of SAS $®$ statistical software (version 9.0 for Windows $®$; SAS, 2002) was used. Treatment means were compared by the test of Tukey at 5\% significance level.

\section{RESULTS AND DISCUSSION}

Table 3 shows the yolk lipid oxidation results of the different treatments, as measured by TBARS.

Table 3 - Lipid oxidation (TBARS values) of the yolks of eggs laid by white layers fed diets supplemented with different vegetable oils.

\begin{tabular}{|c|c|}
\hline Treatment & TBARS (mgTMP/kg) \\
\hline 1 (control) & $0.1700 c$ \\
\hline $2(2.5 \%$ linseed oil) & $0.2583 a b c$ \\
\hline $3(2.5 \%$ canola oil $)$ & $0.2150 a b c$ \\
\hline $4(2.5 \%$ soybean oil $)$ & $0.1467 c$ \\
\hline 5 (5\% linseed oil) & $0.3000 a$ \\
\hline 6 (5\% canola oil) & $0.2000 \mathrm{abc}$ \\
\hline 7 ( $5 \%$ soybean oil) & $0.2217 a b c$ \\
\hline 8 ( $2.5 \%$ linseed oil $+2.5 \%$ soybean oil $)$ & $0.1817 b c$ \\
\hline $9(2.5 \%$ canola oil $+2.5 \%$ soybean oil $)$ & $0.2917 a b$ \\
\hline $10(2.5 \%$ linseed oil $+2.5 \%$ canola oil $)$ & $0.1867 a b c$ \\
\hline Probability & $\mathrm{p}<0.05$ \\
\hline $\mathrm{CV}(\%)$ & 27.32 \\
\hline
\end{tabular}

Means followed by the same letters in the same column are not statistically different by the test of Tukey $(p<0.05)$.

The analysis of variance showed significant yolk lipid oxidation differences among treatments, as shown by TBARS values. After 10 days of storage at room temperature, the eggs laid by hens fed the diet with no oil supplementation or supplemented with $2.5 \%$ soybean oil presented lower yolk lipid oxidation degree than those of hens fed diets supplemented with 5\% linseed oil and with $2.5 \%$ canola oil $+2.5 \%$ soybean 
oil, but were not significantly different from the other treatments. According to Giampietro et al (2008), egg yolk lipid oxidation increase as egg age. These authors detected TBA values of 0.1343 in fresh eggs, which increased to 0.1698 in eggs stored for seven days, and to 0.2138 in eggs stored for 14 days.

Gómez (2003) stated that because polyunsaturated have several double bonds, they are very susceptible to oxidation. Therefore, the egg yolks enriched with these oils are more susceptible to lipid deterioration. This is supported by the results of the present experiment, which detected that the eggs enriched with polyunsaturated fatty acids, laid by hens fed diets supplemented with soybean, canola, and linseed oils, presented high degree of lipid oxidation. In addition, the yolks of the eggs laid by hens fed $5 \%$ linseed oil presented the highest degree of lipid oxidation. This result is consistent with the findings of Gómez (2003), who obtained higher lipid oxidation values in the eggs of layers fed diets with 5\% linseed oil compared with those of hens fed diets with no oil supplementation. That author suggests the higher degree of unsaturation of linolenic acid ( $\omega 3)$ would account for the higher degree of yolk lipid oxidation. Aymond and Van Elswyk (1995) carried out a study to determine TBARS values in the yolk of PUFA $\omega-3$ enriched eggs produced by layers fed diets supplemented with 5 or $15 \%$ intact or ground linseed for five weeks, and did not detect any TBARS differences between linseed treatments and the control (diet with no linseed inclusion). However, in the present experiment, significant differences between the treatment with no oil addition and that with $5 \%$ linseed oil supplementation, indicating that lipid oxidation occurred due the presence of a higher concentration of polyunsaturated fatty acids in the yolk. It is possible that if the antioxidant (BHT) was no included in the experimental diets, a more expressive yolk lipid oxidation would be detected.

Table 4 shows the yolk color results obtained by comparative sensorial assessment and by objective measurement $\left(L^{*}, a^{*}\right.$, and $b^{*}$ values) of the eggs laid by white layers fed diets supplemented with different vegetable oils.

Both colorimetry and sensorial assessment revealed differences among treatments, with egg yolks from hens fed diets supplemented with 5\% canola oil, 5\% soybean oil, and $2.5 \%$ linseed oil $+2.5 \%$ canola oil presented similar yolk pigmentation as that of the eggs of the control treatment (Table 4). However, the pigmentation of the yolks of the eggs laid by hens fed the diet with $5 \%$ soybean oil supplementation were similar only to that of the control treatment and tended to be slightly more intense.

Both colorimetry and sensorial assessment revealed significant differences among treatments, with egg yolks from hens fed diets supplemented with $5 \%$ canola oil, $5 \%$ soybean oil, and $2.5 \%$ linseed oil $+2.5 \%$ canola oil presented similar yolk pigmentation as that of the eggs of the control treatment (no oil). However, the pigmentation of the yolks of the eggs laid by hens fed the diet with $5 \%$ soybean oil supplementation were similar only to that of the control treatment and tended to be slightly more intense.

The analysis of variance showed significant differences among treatments as to redness values. The hens fed diets supplemented with $2.5 \%$ linseed oil $+2.5 \%$ soybean oil produced yolks with lower redness values compared with those produced by hens fed the diets with no oil inclusion or supplemented with $2.5 \%$

Table 4 - Average yolk color values, as determined by sensorial assessment and instrumental measurement, of the eggs laid by white layers fed diets supplemented with different vegetable oils.

\begin{tabular}{|c|c|c|c|c|}
\hline Treatments & $\begin{array}{l}\mathrm{L}^{*} \\
\text { (luminosity) }\end{array}$ & $\begin{array}{l}a^{*} \\
\text { (redness) }\end{array}$ & $\begin{array}{l}b * \\
\text { (yellowness) }\end{array}$ & $\begin{array}{l}\text { Sensorial attribute } \\
\text { Yolk color }\end{array}$ \\
\hline T1 no oil addition & 86.29 & $-2.41 c d$ & $42.45 a$ & $5.00 \mathrm{~cd}$ \\
\hline T2 $2.5 \%$ linseed oil & 85.55 & $-2.48 b c d$ & $37.68 a b$ & $2.86 a b$ \\
\hline T3 $2.5 \%$ canola oil & 85.36 & $-2.24 d$ & $41.20 a$ & $2.60 \mathrm{ab}$ \\
\hline T4 2.5\% soybean oil & 86.33 & $-3.06 a b$ & $39.26 a b$ & $2.17 a$ \\
\hline T5 5\% linseed oil & 86.31 & $-2.87 a b c d$ & 35.89ab & 3.39ab \\
\hline T6 5\% canola oil & 86.06 & $-2.63 b c d$ & $34.94 a b$ & $3.86 b c$ \\
\hline T7 5\% soybean oil & 86.52 & $-2.53 b c d$ & $39.67 a b$ & $5.60 d$ \\
\hline T8 $2.5 \%$ linseed oil $+2.5 \%$ soybean oil & 86.55 & $-3.39 a$ & $41.97 a$ & $2.95 a b$ \\
\hline T9 $2.5 \%$ canola oil $+2.5 \%$ soybean oil & 86.26 & $-2.85 a b c d$ & $37.83 a b$ & $3.13 a b$ \\
\hline T10 $2.5 \%$ linseed oil $+2.5 \%$ canola oil & 86.28 & $-2.92 a b c$ & $32.38 b$ & $3.78 \mathrm{bc}$ \\
\hline Probabilidade & $p>0.05$ & $p<0.05$ & $p<0.05$ & $p<0.05$ \\
\hline CV $(\%)$ & 1.32 & 14.49 & 12.05 & 38.69 \\
\hline
\end{tabular}

Means followed by the same letters in the same column are not statistically different by the test of Tukey $(p<0.05)$. 
linseed oil, 2.5\% canola oil, 5\% canola oil, and 5\% soybean oil. Moreover, the yolks of the eggs laid by layers supplemented with $2.5 \%$ canola oil tended to present higher redness values compared with those of hens fed diets supplemented with $2.5 \%$ soybean oil, $2.5 \%$ linseed oil $+2.5 \%$ soybean oil, and $2.5 \%$ linseed oil $+2.5 \%$ canola oil.

Yellowness ( $b$ * values) were also significantly different among treatments. The egg yolks of layers fed diet with no oil supplementation or supplemented with $2.5 \%$ canola oil, $2.5 \%$ linseed oil $+2.5 \%$ soybean oil presented higher $b$ * values than those of hens supplemented with $2.5 \%$ linseed oil $+2.5 \%$ canola oil, but were not significantly different from the other treatments. Higher yellowness values were detected in the eggs of layers fed the diet with no oil supplementation, which may be explained by the higher inclusion of corn, which has natural pigments, in this diet. Perhaps a higher number of yolks sampled may have yielded statistical differences. Xanthophylls are red or yellow carotenoid pigments responsible for yolk color and are present in some plants such as corn, which contains approximately $20 \mathrm{mg} \mathrm{kg}^{-1}$ (Cheeke, 1999).

No luminosity differences ( $p>0.05$ ) were detected among treatments.

Carbó (1987) mentioned that the inclusion of fats in the diet aid the transfer of feed carotenoids to the egg yolk because dietary carotenoids and xanthophylls are fat soluble, that is, the intestinal absorption of these pigments is optimized when lipids are added to the diet. The results of the present study seem to suggest that the applied lipid sources did not contain pigments capable of affecting yolk color intensity. Carbó (1987), on the other hand, observed that the inclusion of antioxidants in diets rich in unsaturated fatty acids, which are susceptible to oxidation, improves yolk pigmentation. In addition, that author mentions that, when the dietary lipids produce peroxides, yolk pigmentation maybe negatively affected due to the oxidation of carotenoids.

\section{ACKNOWLEDGEMENTS}

The authors thank FAPESP for the research grant.

\section{CONCLUSIONS}

It was concluded that the supplementation of commercial white layer diets with vegetable oils does not considerably change egg yolk pigmentation, as colorimetrically evaluated. However, when subjectively assessed, the yolks of the eggs laid by hens fed diets supplemented with vegetable oils tend to be paler.

The yolks of the eggs laid by layers fed the diet with $5 \%$ linseed oil (rich in omega-3 polyunsaturated fatty acids) presented high lipid oxidation, particularly when compared with those derived from layers fed the diet with no oil supplementation.

\section{REFERENCES}

Alleoni ACC, Antunes, AJ. Unidade Haugh como medida da qualidade de ovos de galinha armazenados sob refrigeração. Scientia Agrícola 2001;58(4):681-685.

Aymond WM, Van ElswykME. Yolk thiobarbituric acid reactive substances and n-3 fatty acids in response to whole and ground flaxseed. Poultry Science 1995;74:1388-1394

Barreto SCS, Zapata JFF, Freitas ER, Fuentes MFF, Nascimento RF, Araújo RSRM, et al. Ácidos graxos da gema e composição do ovo de poedeiras alimentadas com rações com farelo de coco. Pesquisa Agropecuária Brasileira 2006;41(12):1767-1773.

Bible BB, Singha S. Canopy position influences coordinates of peach color. Hortscience 1997;28:992-993.

Botsoglou NA, Yannakopoulos AL, Fletouris DJ, Tserveni- Goussi AS, Psomas IE. Yolk fatty acid composition and cholesterol conten in resnponse to level and form of dietary flaxseed. Journal of Agricultural and Food Chemistry 1998;46(11):4652-4656.

Braga JP, Baião NC. Suplementação lipídica no desempenho de aves em altas temperaturas. Cadernos Técnicos de Veterinária e Zootecnia $2001 ; 34: 23-28$

Cadun A, Cakli S, Kisla D. A study of marination of deepwater pink shrimp (Parapenaeus longirostris, Lucas, 1846) and its shelf life. Food Chemistry 2005;90(1-2):53-59.

Carbo CB. La gallina ponedora: sistemas de exploração y técnicas de producción. Madrid: Ediciones Mundi-Prensa; 1987.

Cheeke PR. Applied animal nutrition: feeds and feeding. 2nd ed. New Jersey: Pretince-Hall; 1999.

Cherian G. Egg quality and yolk polyunsaturated fatty acid status in relation to broiler breeder hen age and dietary n-3 oils. Poultry Science 2008;87(6):1131-1137.

Cherian G, Traber MG, Goeger MP, Leonard SW. Conjugated linoleic acid and fish oil in laying hen diets: effects on egg fatty acids, thiobarbituric acid reactive substances, and tocopherols during storage. Poultry Science 2007;86(5):953-958

Fennema OR. Química de los alimentos. 2nd ed. Zaragoza: Editorial Acribia; 2000.

Giampietro A, Scatolini AM, Boiago MM, Coró DMO, Souza Alves HB, Souza PA, et al. Estudo da metodologia de TBARS em ovos. Produção Animal 2008;18.

Gómez MEDB. Modulação da composição de ácidos graxos poliinsaturados ômega 3 de ovos e tecidos de galinhas poedeiras, através da dieta. I: estabilidade oxidativa [tese]. São Paulo (SP): Universidade de São Paulo; 2003

Grosch HDB. Química de los alimentos. Zaragoza: Editorial Acribia; 1997. 
Honikel KO. Reference methods for the assessment of physical characteristics of meat. Meat Science 1998;49(4):447-457

Lee BD, Kim DJ, Lee SJ. Nutritive and economic values of high oil corn in layer diet. Poultry Science 2001;80:1527-1534.

Oliveira DD. Fontes de lipídios na dieta de poedeiras: Efeito sobre a produção e o perfil de ácidos graxos na gema [tese]. Belo Horizonte (MG): UFMG-Escola de Veterinária; 2008.

Osawa CC, Felício PE, Gonçalves LAG. Teste de TBA aplicado a carnes e derivados: métodos tradicionais, modificados e alternativos. Química Nova 2005;28(4):655-63.

Pita MCG, Piber Neto E, Carvalho PR, Mendonça Jr CX. Efeito da suplementação de linhaça, óleo de canola e vitamina $E$ na dieta sobre as concentrações de ácidos graxos poliinsaturados em ovos de galinha. Arquivo Brasileiro de Medicina Veterinária e Zootecnia 2006;58(5):925931.

Ramanathan L, Das NP. Studies on the control of lipid oxidation in ground fish by some polyphenolic natural products. Journal of Food Chemistry 1992;40(1):17-21.

Roça RO, Bonassi IA. Seleção de provadores para produtos cárneos. Anais do $7^{\circ}$ Congresso Brasileiro de Ciência e Tecnologia de Alimentos; 1985; Ilhéus. Brasil. p.83.

Roça RO, Serrano AM, Bonassi IA. Utilização de toucinho na elaboração de fiambres com carne de frango. Ciência e Tecnologia de Alimentos 1988;8(1):67-76
Rostagno HS, Albino LFT, Donzele JL, Gómez PC, Oliveira RF, Lopes DC, et al. Tabelas brasileiras para aves e suínos: composição de alimentos e exigências nutricionais. Viçosa: Universidade Federal de Viçosa; 2005.

SAS Institute. Getting started with the SAS learning edition. Care; 2002.

Schreiner M, Hulan HW, Razzazi- Fazeli E, Böhm J, Iben C. Feeding laying hens seal blubber oil: effects on egg yolk incorporation, stereospecific distribution of omega-3 fatty acids, and sensory aspects. Poultry Science 2004:83:462-473.

Silva JHV, Albino LFT, Godoi MJS. Efeito do extrato de urucum na pigmentação da gema dos ovos. Revista Brasileira de Zootecnia 2000;29(5):1435-1439

Szymozyk B, Pisulewski PM. Effects of dietary conjugated linoleic acid on fatty acid composition and cholesterol content of hen egg yolks. British Journal of Nutrition 2003:90(1):93-99.

Tocchini L, Mercadante AZ. Extração e determinação, por CLAE, de bixina e norbixina em coloríficos. Ciência e Tecnologia de Alimentos 2001:21(3):310-313.

Vyncke BW. Direct determination of the thiobarbituric acid value in trichloracetic acid extracts of fish as a measure of oxidative rancidity. Fette-Scifen Anstrichmittel 1970;72(12):1084-1087.

Xavier IMC, Cançado SV, Figueiredo TC, Lara LJC, Lana AMQ, Souza MR, et al. Qualidade de ovos de consumo submetidos a diferentes condições de armazenamento. Arquivo Brasileiro de Medicina Veterinária e Zootecnia 2008;60(4):953-959. 
